\title{
International Diversification and MNE Innovativeness: A Contingency Perspective of Foreign Subsidiary Portfolio Characteristics
}

\author{
Mashiho Mihalache ${ }^{1}$ D Oli R. Mihalache ${ }^{2,3} \cdot$ Jan van den Ende ${ }^{4}$
}

Received: 5 August 2020 / Revised: 14 December 2021 / Accepted: 21 December 2021 /

Published online: 4 February 2022

(c) The Author(s) 2022

\begin{abstract}
We advance research on how international diversification affects MNEs' innovativeness by reconciling contradictory views on the role of international diversification for innovation. We do so by developing a portfolio perspective of MNE innovation that moves beyond foreign R\&D subsidiaries to consider firms' entire international footprints and by theorizing that MNE innovativeness depends on the interplay of geographical (i.e., regional diversification and institutional distance) and organizational (i.e., asset diversification and functional mandate breadth) characteristics of the foreign subsidiary portfolio. We test our proposed relationships on a unique multi-source panel dataset of Japanese listed electronics firms (266 firms and their 4505 subsidiaries between 2007 and 2015 resulting in 1936 firm-year observations and 28,350 subsidiary-year observations). We find that the institutional distance and asset diversification of the foreign subsidiary portfolio constrain the extent to which geographical (regional) diversification can enhance MNEs innovativeness. We also find that, at high levels of geographical diversification, MNEs with low levels of institutional distance and asset diversification in the foreign subsidiary portfolio tend to achieve higher innovativeness. Lastly, we did not find empirical support for functional mandate breadth as affecting how geographical diversification influences MNE innovativeness. Overall, the study highlights that, for a nuanced understanding of MNE innovativeness, managers need an encompassing and deliberate portfolio-level strategy that explicitly considers the interrelatedness of geographical and organizational characteristics.
\end{abstract}

Keywords Innovation · International diversification $\cdot$ Multinationals $\cdot$ Foreign subsidiary portfolio $\cdot$ International strategy

Mashiho Mihalache

m.mihalache@uva.nl

Extended author information available on the last page of the article 


\section{Introduction}

International business research increasingly acknowledges that by going abroad firms can not only exploit their current capabilities, but also can develop new capabilities (Jha et al., 2018; Kuemmerle, 1999; Lin, 2020). While foreign locations are potential sources of new technical, market, and functional knowledge as well as other resources for innovation (e.g., Cano-Kollmann et al., 2016; da Silva Lopes et al., 2019; Michailova \& Mustaffa, 2012), not all organizations can successfully leverage these opportunities. Since foreign locations have different factor and demand characteristics (Feinberg \& Gupta, 2004), different international footprints will provide different opportunities for innovation.

However, while internationalization creates opportunities for stimulating innovation, realizing these opportunities is not straight forward. This can be seen in the contradictory arguments and findings of previous research that link more extensive and diverse foreign operations to more innovation due to a more diverse knowledge and resource base (Narula \& Zanfei, 2005; Nieto \& Rodríguez, 2011; Tojeiro-Rivero \& Moreno, 2019), to less innovation since the heavier reliance on foreign knowledge can hallow out organizations and overburden managerial attention (Bahl et al., 2021; Chen \& Lin, 2018), or to nonlinear relationships where the negative effects manifest at high levels of internationalization (Chen et al., 2012; Mihalache et al., 2012). We argue that this unclarity is due to at least two reasons. First, previous research that tried to understand MNE innovativeness focuses on the geographical diversification of only R\&D subsidiaries (cf., Vrontis \& Christofi, 2019). But innovation is not only about foreign R\&D as recent research shows that other types of subsidiaries significantly contribute to innovation. For instance, sales and marketing subsidiaries challenge the MNE to develop new products and services as they encounter customers with different preferences (Azar \& Drogendijk, 2014; Govindarajan \& Ramamurti, 2011; Holm \& Sharma, 2006; Huang \& Li, 2019; Immelt et al., 2009) and provide complementary assets to research activities (Lampert et al., 2019). Also, manufacturing subsidiaries give feedback on current processes and products that enables new technologies to be developed (Gupta \& Govindarajan, 2000) and provide knowledge that, when combined with knowledge in other parts of the organization, can help MNEs to innovate (Berry, 2014). Moreover, innovation is not only about knowledge, but also about other types of resources associated with internationalization such as access to cheaper labor and financing (Mihalache et al., 2012). Thus, the mixed ideas and findings in the literature regarding geographical diversification may be due to previous research's omission of non-R\&D activities that MNEs perform across their global network of subsidiaries and that provide important resources for innovation.

The second reason for the unclarity regarding the influence of geographical diversification on MNE innovation is because of a lack of attention to the interplay between geographical diversification and other characteristics of MNEs' subsidiary portfolio. Since previous research on MNE innovation captures internationalization predominantly by considering a single type of foreign activity-focusing 
either on subsidiaries with a research (e.g., Lahiri, 2010; Penner-Hahn \& Shaver, 2005) or sales (e.g., Bahl et al., 2021; Wu et al., 2016) mandate-the interplay between different characteristics of the entire subsidiary portfolio has been overlooked. This can be particularly limiting in our understanding of innovation as MNEs' knowledge stock is an accumulation of knowledge from all of its foreign subsidiaries and depends on their inter-relationship (Meyer et al., 2020). Thus, the mixed findings and arguments of previous research can be attributed to the omission of the fact that knowledge often resides in invisible communities of practice that cross the physical boundaries of a particular subsidiary (Mudambi $\&$ Swift, 2011). Therefore, our study raises the question: How does geographical diversification affect MNE innovativeness and how does this relationship depend on other characteristics of the MNEs' international subsidiary portfolio?

This study contributes to international business research by developing and empirically testing a portfolio perspective of MNE innovativeness that can reconcile the contradictory ideas about the influence of geographical diversification on innovativeness. First, our study shows that considering the entire international footprint is important for understanding how MNEs can leverage international operations to become more innovative. We complement the large body of research on R\&D internationalization (for a recent review, see Papanastassiou et al., 2020), by shifting perspective to the MNEs' overall international footprint in order to explore the entire knowledge base of MNEs (Hutzschenreuter \& Matt, 2017). In this way, we answer a research call for expanding previous focused conceptualizations to "a conceptualization of international diversification that encompasses the full range of activities that determine the geographic scope of a firm" (Wiersema \& Bowen, 2011, p. 152).

Second, our portfolio perspective provides a nuanced understanding of how geographical diversification affects MNEs' innovativeness by proposing that its effect depends on the interplay with other characteristics of the MNE's subsidiary portfolio as these enable or constrain how MNEs can access and use knowledge from foreign locations. Specifically, we consider four characteristics of their international footprint: regional diversification (i.e., the extent to which an MNE tends to concentrate its foreign subsidiaries in a few geographical regions or spread them across regions), institutional distance in their subsidiary portfolio (i.e., the extent to which the subsidiaries tend to be located in countries that are more distant in terms of the perceived corruption), asset diversification (i.e., the extent to which the foreign subsidiaries are operating in different industries than that of the parent firm), and functional mandate breadth (i.e., the extent to which subsidiaries tend to perform multiple activities rather than specializing on a particular function). The portfolio perspective we advance in this study is critical because we show that MNE-level innovation is not only about the capabilities of a particular subsidiary (e.g., Driffield et al., 2016), but that innovation depends on the interplay between locational and organizational elements of the foreign subsidiary portfolio. This advances the underlying logic of internationalization theory, in which locational advantages are combined with organizational capabilities (Rugman et al., 2011a, b). Thus, our study suggests that to stimulate innovativeness, MNEs should make portfolio-level decisions rather than focus on individual subsidiaries. 
To test the proposed relationships, we developed a unique longitudinal and multisource dataset of Japanese listed electronics firms and their foreign subsidiaries (266 firms and their 4505 subsidiaries between 2007 and 2015 resulting in 1936 firmyear observations and 28,350 subsidiary-year observations). Our findings suggest that a portfolio perspective provides important insights into MNEs' ability to innovate. Importantly, we find that whether regional geographical diversification within the subsidiary portfolio enhances or dampens MNE innovativeness depends on two other characteristics of the portfolio-institutional distance and asset diversification.

\section{Theoretical Foundations}

The advances in telecommunication technology and the trade liberalization of the last two decades have led MNEs to increasingly try to leverage locational advantages by performing multiple value chain activities abroad. In line with these developments, we follow Wiersema and Bowen's (2011, p. 155) conceptualization of internationalization as comprising "all foreign aspects of a firm's value chain, from the geographic markets where it sells its products/services to the global locations where it produces its products/services and the geographic locations where its capabilities reside". That is, in addition to the well-studied revenue-seeking internationalization (e.g., Hitt et al., 2006, 2007), MNEs increasingly establish foreign subsidiaries that engage in various value-chain activities such as innovation, manufacturing, administrative and IT support (Lewin \& Peeters, 2006; Mihalache \& Mihalache, 2020). International business research has mirrored these developments in practice and tried to understand how MNEs can leverage their global footprint.

However, there is a paucity of research focused on understanding how international diversification affects MNE innovation, although research is plentiful in two related topics. First, there is an abundance of research on how international diversification affects MNEs' financial performance, with research proposing various relationships including non-linear ones (Delios \& Beamish, 1999; Goerzen \& Beamish, 2003; Lu \& Beamish, 2004; Nachum, 2004; Qian et al., 2008). Second, there is a well-established line of research on the relationship between the internationalization of R\&D and firm innovation (e.g., Hsu et al., 2015; for a recent review, see Vrontis \& Christofi, 2019). The lack of research on how international diversification of all foreign activities affects MNE innovativeness leaves an important lacuna in our understanding because other activities besides $R \& D$ also contribute to innovation. For instance, manufacturing can enable the development of new technologies through feedback loops (Gupta \& Govindarajan, 2000) and sales provides key knowledge on different customer needs as is the case of reverse innovation (Govindarajan \& Ramamurti, 2011; Immelt et al., 2009). Furthermore, it is essential to consider all foreign activities when trying to understand how international diversification affects MNE innovation because there are important interdependencies between all business functions for innovation. By considering how the entire foreign footprint affect MNEs' innovativeness, we are also responding to calls for international business research to return to the original conceptualization of MNE internationalization, which captures 
the global pattern of all the value-chain activities (Asmussen et al., 2007; Wiersema \& Bowen, 2011).

In this study we draw on the knowledge based view of the firm and consider firms as a bundle of knowledge resources (Grant 1996). With its focus on knowledge integration and creation, the knowledge-based view provides a strong basis for understanding innovation in MNEs. As innovation lies in the combination of knowledge in new ways (Kogut \& Zander, 1992), internationalization, in its core, can enable MNEs to innovate by providing access to diverse knowledge resources from different parts of the world. This opportunity to source and interpret knowledge through its foreign subsidiaries embedded in different environments, provides MNEs an advantage in knowledge creation compared to organizations lacking international operations (Regner \& Zander, 2011). Specifically, in this study, we conceptualize internationalization in terms of regional geographical diversification, which refers to the extent to which the international footprint of MNE is spread out across geographical regions. Geographical diversification at the regional level draws from the semi-globalization perspective (Ghemawat, 2003). As the economic integration between countries increased over recent decades (Buckley et al., 2001), the differences between regions have become more pronounced than the differences between countries. Regions are generally made up of geographically close countries that have taken measures to integrate economically, for example, through free-trade agreements (Arregle et al., 2013; Rugman et al., 2011a, b). Supporting this perspective, empirical evidence shows that regional factors influence the location decisions of MNEs above and beyond country-level factors (Arregle et al., 2009, 2013, 2016). Conceptualizing geographical diversification at the regional level because this allows us to focus on the level where most differences are likely to be felt.

We consider three key contingencies of the effectiveness of internationalization in stimulating innovation: institutional distance, asset diversification, and functional mandate breadth. We focus on these three moderators specifically because, in line with the tenets of the knowledge-based view, the advantages afforded by internationalization for knowledge creation depend on knowledge overlap, knowledge diversity, and the external environments in which MNC subsidiaries are embedded (Regnér $\&$ Zander, 2011). To capture the external context in which the MNE's knowledge is embedded, we consider the contingency role of the institutional distance of the subsidiary portfolio, which refers to the differences in institutional contexts between the home country and the subsidiaries' country (Kostova, 1999). Since institutions determine the rules, regulations as well as the norms for doing business in a particular country influencing not only what is legal but also what is acceptable in a particular country (Kostova et al., 2020), institutional distance implies an unfamiliarity with the rules of the game in a foreign location (Shirodkar \& Konara, 2017). Previous studies adopting a knowledge-based view of MNEs, specifically highlight the country as a boundary condition for the value of resources and capabilities available (Matysiak et al., 2018). Therefore, institutional distance is particularly important when discussing MNEs' innovativeness because it affects the extent to which MNEs can access and use knowledge from foreign locations.

Furthermore, to capture knowledge overlap and diversity, we consider the asset diversification and the functional mandate of the MNE's subsidiary portfolio. The 
asset diversification of the subsidiary portfolio refers to the extent to which the foreign subsidiaries tend to have a similar of different asset base compared to the parent firm. Asset diversification generally depends on whether the subsidiary is involved in the same or different line of business as the parent firm. The second organization characteristics we focus on is subsidiary functional mandate breadth. As we detailed at the beginning of this section, subsidiaries can perform a variety of functions. The functional mandate breadth captures this variety and indicates whether an MNE tends to establish more specialized or more multi-function subsidiaries, affecting the diversity of knowledge within subsidiaries.

In the next section, we develop hypotheses about how internationalization affects MNE innovation and key boundary conditions.

\section{Hypotheses Development}

\subsection{The Influence of Geographical Regional Diversification on MNE Innovativeness}

When viewing the MNE as a network of subsidiaries, its fundamental purpose becomes that of coordinating the flow of knowledge and resources across its global operations (Rugman et al., 2011a, b; Williams \& Lee, 2011). Narula (2017, p. 214) labels MNEs as "meta-integrators" and highlights the need to promote knowledge flows between its foreign subsidiaries. Birkinshaw and Pedersen (2009) hold that to understand the true value of a subsidiary's resources one needs to take into account how these can be combined with those from other subsidiaries and how they can be leveraged by the overall MNE. In addition, innovation research shows that a firm's innovativeness depends on its resources and its ability to combine these resources in new ways (Kotabe et al., 2007; Pennings \& Harianto, 1992). Building on these ideas, we argue that the extent to which MNEs can take advantage of global opportunities for innovation depends on the resources their international footprint makes available and MNE's ability to integrate these geographically dispersed resources.

Geographical regional diversification can enhance MNEs' innovativeness in several ways. First, regional diversification increases the diversity of the MNEs' knowledge base because its subsidiaries are embedded in more distinct environments (Ghoshal \& Nohria, 1989; Luo \& Peng, 1999). That is, organizations whose portfolios are more dispersed across different regions are more likely to have access to more diverse knowledge resources. As MNEs increasingly recognize foreign subsidiaries as important sources of knowledge and emphasize the outflow of knowledge into the parent firm (Ambos et al., 2006; Crespo et al., 2014; Michailova \& Mustaffa, 2012; Tippmann et al., 2012; Yang et al., 2008), the diversity of knowledge firms can access increases the likelihood that firms engage with recent technologies, preventing them from remaining blocked with obsolete ones. In line with this idea, Leiponen and Helfat (2010) find that the breadth of knowledge sources in organizations' search processes is associated with higher innovativeness. The breadth of knowledge search processes stimulates organizational innovativeness because knowledge diversity provides more possibilities for combining knowledge in new 
ways (Almeida et al., 2002; Katila \& Ahuja, 2002; Kogut \& Zander, 1992; Roper \& Hewitt-Dundas, 2015). Similarly, regional diversification means that MNEs come in contact with customers with more distinct needs and expectations, which can act as a demand pool for innovation (Huang \& Li, 2019). Essentially, MNEs who have greater regional diversification are likely to face more problems that need creative solutions than MNEs that tend to concentrate their operations in fewer geographical regions. Thus, when operating in more geographical regions, MNEs are exposed to more distinct customer demands, new technologies and different capabilities embedded in these environments.

Second, diversification across geographical regions can enhance MNEs' innovativeness because it provides more diverse foreign contexts in which firms engage in the innovation process. Since foreign locations differ in their resource endowments (Cantwell, 1989; Meyer et al., 2011), firms can leverage differences in input factors between locations such as the availability and cost of labor, knowledge accessibility, and government incentives (Arregle et al., 2013; Lewin \& Peeters, 2006). For instance, large pools of qualified workers can allow to increase research activities at lower costs and the availability of specialized service providers can lower costs and enable firms to divert funds to innovation activities (Mihalache et al., 2012). That is, regional diversification provides access to different factors important for innovation that can allow them to more effectively deploy innovation processes. To put it differently, regional diversification creates diversity in the contexts in which MNEs operate, allowing them to leverage idiosyncratic resources and capabilities for innovation.

Therefore, we propose that greater regional diversification can stimulate MNE innovativeness because it potentially provides more diverse knowledge resources and more diverse environments conducive to innovation.

Hypothesis 1: There is a positive relationship between geographical (regional) diversification and MNE innovativeness.

\subsection{The Contingency Effects of the Foreign Subsidiary Portfolio Characteristics: Institutional Distance, Asset Diversification, and Functional Mandate Breadth}

\subsubsection{Institutional Distance}

We argue that the institutional distance of the foreign subsidiary portfolio acts as a constraint on MNEs' ability to leverage regional diversification to increase innovativeness. Fundamentally, MNEs whose subsidiary portfolios exhibit higher levels of institutional distance have their global resources embedded in countries in which the rules of doing business differ more from those in the parent's country. Since institutional distance increases the complexity of doing business (Kostova et al., 2020), institutional distance translates into more limited access and use or higher costs in leveraging foreign resources, thus dampening the extent to which geographical diversification stimulates MNE innovativeness. Institutional distance increases the costs and risks of managing foreign locations as MNEs have a lower understanding of how to operate in these distant institutional environments, leading 
to more inefficient transactions (Kostova \& Roth, 2002). Previous research finds that institutional distance constrains subsidiaries' competence creating abilities (Asmussen et al., 2009; Williams \& Nones, 2009), their own innovation process (Rodrigues et al., 2020), and their overall performance (Shirodkar \& Konara, 2017). Therefore, although geographical diversification implies access to diverse resource, it is more challenging for MNEs to access and use these resources when their subsidiaries tend to be located in more institutionally different countries.

Furthermore, higher levels of institutional distance in the subsidiary portfolio may constrain the influence of geographical diversification on MNE innovativeness because they make it more difficult to combine the organization's globally distributed resources. This is because high institutional distance in the subsidiary portfolio means that organizations are not likely to be able to rely on the same institutions as they do at home when leveraging resources (Khanna \& Palepu, 1997), making coordination of resources more difficult and less effective. Wu and Park (2019) argue that institutional complexity makes coordination of geographical dispersed resources more difficult as it leads to information overload for managers. In line with these ideas, research finds that headquarters tend to benefit more from knowledge coming from locations with similar characteristics because of the similar expectation in knowledge structure and better fit in the conventions with the foreign subsidiary providing the knowledge (Ambos et al., 2006). Also, research shows that institutional distance reduces headquarter support for subsidiary initiative due to perceived relational distance (Raziq et al., 2021). Therefore, institutional distance constrains MNE's ability to leverage geographical distance for innovation because it makes it more difficult for the subsidiaries to tap into foreign resources and for the MNE to recognize the value and combine geographically dispersed resources.

Hypothesis 2: The institutional distance of the foreign subsidiary portfolio negatively moderates the positive relationship between geographical (regional) diversification and MNE innovativeness.

However, to understand the influence of geographical diversification on MNE innovativeness, we need to understand its relationship also with the organizational characteristics of the foreign subsidiary portfolio. Next, we will focus on the contingency roles of two organizational characteristics: asset diversification and functional mandate breadth.

\subsubsection{Asset Diversification}

Asset diversification of the foreign subsidiary portfolio refers to the extent to which subsidiaries use an asset base that differs or is similar to that of the parent firm. Generally, the asset base of the subsidiary portfolio will be similar when subsidiaries are engaged in the same line of business as the parent but will be diversified when it comprises resources and knowledge that are different from those of the parent's business (Luo, 2002). Operating in an industry that is different from its parent, foreign subsidiaries can contribute to the MNE's overall diversity of assets as it provides exposure to new market and technological knowledge (Li, 1995). The consequence 
is that MNEs who have higher levels of asset diversification in their foreign subsidiary portfolio are likely to have more diverse knowledge and resources.

The asset diversification of the foreign subsidiary portfolio may inhibit MNEs' ability to leverage geographical diversification to stimulate MNE innovativeness. That is, increasing geographical diversification is likely to enhance innovation more when the international subsidiary portfolio has low rather than high levels of asset diversification. There are at least two reasons for this. First, the high levels of asset diversification may make it more difficult to integrate the parent firm's knowledge base and the geographically dispersed knowledge of the foreign subsidiaries. A high level of asset diversification can hamper knowledge transfer from geographically dispersed subsidiaries because the knowledge does not relate to that of the parent MNE (Lu \& Xu, 2006). Since connectedness stimulates inter-unit knowledge transfer (Kijkuit \& Ende, 2010), asset diversification reduces the parent firm's ability to draw on its geographically dispersed knowledge. Knowledge transfer is further hindered because operating in different industries often requires foreign subsidiaries to employ different routines and processes from the parent firm (Jiang et al., 2010).

Furthermore, high levels of asset diversification in the subsidiary portfolio may make it more difficult for MNEs to leverage geographical diversification due to added complexity. The increased complexity (Anderson, 1999) that the asset diversification of the subsidiary portfolio brings to the already difficult management of operations that are widely dispersed across different geographical regions (Jensen et al., 2013) may create coordination problems. In other words, coordinating geographically dispersed resources for innovation may be easier when the foreign subsidiaries in control of these resources have more common ground and can more easily interact with the parent firm (i.e., at lower levels of asset diversification of the subsidiary portfolio). In addition, the added complexity associated with high asset diversification increases demands on managerial attention (Chesbrough \& Teece, 1996; Rothaermel et al., 2006), making it more difficult to take advantage of the innovation opportunities associated with geographical diversification. Considering these arguments, we propose the following hypothesis:

Hypothesis 3: The asset diversification of the foreign subsidiary portfolio negatively moderates the positive relationship between geographical (regional) diversification and MNE innovativeness.

\subsubsection{Functional Mandate Breadth}

Functional mandate breadth of the foreign subsidiary portfolio denotes the extent to which the foreign subsidiaries perform multiple value-chain activities. MNEs foreign subsidiary portfolios differ in terms of their subsidiary functional mandates such that while some MNEs opt for more subsidiaries that specialize in a particular function that fits the local environment, others may undertake multiple functions (Kedia \& Mukherjee, 2009). That is, in line with Rugman et al. (2011a, b), subsidiaries can potentially engage in a range of activities from competence-exploiting ones such as sales to competence-creating ones such as research and development. The subsidiary functional mandate breadth is important because it affects not only 
the activities the subsidiaries engage in and, consequently, the resources they can access, but also how they relate to the rest of the MNE (Lee et al., 2020; Meyer et al., 2020).

MNEs may be better able to leverage geographical diversification for innovation at low rather than high levels of functional mandate breadth of the foreign subsidiary portfolio. Since the basic premise of how geographical diversification enhances innovation is that it provides diverse resources for innovation, higher functional mandate breadth in the foreign subsidiary portfolio may make it less likely that subsidiaries contribute and use resources from other parts of the MNE. When subsidiaries have higher functional mandate breadth, they can leverage synergies between the functions in their own locations such as between marketing and R\&D (Song et al., 2005) rather than relying on other subsidiaries. Conversely, subsidiaries with lower functional mandate breadth might be more willing to share resources to showcase their worth within the global organization and ensure a continuing flow of resources from the parent firm and other subsidiaries (Berry, 2014; Mudambi, 1999). Since we know that subsidiaries' influence within the MNE affects their knowledge transfer (Ciabuschi et al., 2010; Najafi-Tavani et al., 2014), when MNEs have a portfolio of more specialized subsidiaries (i.e., lower functional mandate breadth) they are likely to have a more vibrant flow of knowledge and resources; thus, such MNEs can better leverage the diverse resource base associated with their geographical diversification. Therefore, we propose the following hypothesis:

Hypothesis 4: The functional mandate breadth of the foreign subsidiary portfolio negatively moderates the positive relationship between geographical (regional) diversification and MNE innovativeness.

\section{Methods}

\subsection{Data and Sample}

To test these hypotheses, we developed a multi-source panel dataset of the Japanese electronics industry between 2007 and 2015. The electronics industry is an important economic driver of the Japanese economy, accounting for $20 \%$ of its manufactured product exports (Japan Ministry of Economy, Trade \& Industry, 2017). It is also an appropriate context in which to test hypotheses about MNE innovativeness due to its high R\&D investment - the highest (28.4\%) in the country (Japan Ministry of Economy, Trade and Industry 2017) — and the propensity of electronics firms to internationalize. Focusing on one industry helps us control for potential confounds on the innovativeness variable, such as the nature of products or markets. Because of this advantage, single-industry studies are common in management studies, for instance, in health care (Proksch et al., 2019; Sampat \& Shadlen, 2017; Zheng \& Yang, 2015), manufacturing (Foucart \& Li, 2021; Gao et al., 2021), aerospace (Speldekamp et al., 2020), telecommunication (Clò et al., 2020; Nambisan, 2013) or food industry (Trott \& Simms, 2017). 
We compiled a unique database by collecting information from three different data sources. First, we used Toyo Keizai Inc.' Kaisha Shikiho database, which contains financial information on all Japanese listed companies. We obtained a list of all publicly listed companies in the electronics industry and collected information on firm characteristics and financials. We consider that data from Toyo Keizai Inc. is highly reliable as it is frequently used by worldwide rating agencies and in previous academic studies (e.g., Arregle et al., 2013; Lu \& Beamish, 2006). Second, we obtained information on these firms' foreign subsidiaries from the Kaigai Shinshutsu Kigyo Soran, a directory of Japanese listed companies doing business abroad (Toyo Keizai, 2010). Third, we collected data on firms' innovativeness from the World Intellectual Property Organization's Patentscope database that contains patents applied for at the Japan Patent Office. In total, our dataset comprises 266 MNEs (1936 firm-year observations) and their 4505 subsidiaries $(28,350$ subsidiary-year observations, which we aggregated to calculate firm-level portfolio characteristics). Since some firms go out of business and new ones are established, this is an unbalanced panel, with an average of 7.3 years per company out of the maximum of 9 years within our study period. The MNEs in our sample have, on average, 17 subsidiaries and the average subsidiary age is 18 years. Furthermore, the MNEs have an average of five manufacturing subsidiaries, eight sales subsidiaries, one R\&D subsidiary, and three administrative subsidiaries. As an indication of internationalization experience, on average, the oldest active subsidiary is 27 years old.

\subsection{Measures}

\subsubsection{Dependent Variable}

Firm innovativeness is measured as the number of patents applied for at the Japan Patent Office with a 1-year delay $(\mathrm{t}+1)$. While the suitability of patents for measuring innovativeness has been sometimes questioned, the use of patents in management studies has been dramatically increasing (Savage et al., 2020). We consider that patents are an appropriate measure here as our study circumvents the main issues associated with patents. First, our single industry reduces the danger of between-industry differences in patenting tendencies. Second, we avoid the criticism that not all inventions are patented (Griliches, 1998), since firms in the electronics industry have a proclivity to patent to protect their knowledge base: Motohashi (2008) finds it to have the highest average number of patents per firm in Japan and there is a high correlation between the patent counts and other measure of innovativeness such as R\&D expense and new product development performance (Hagedoorn \& Cloodt, 2003). Third, we do not take multiple variables from the patents-related information, which is often criticized for biasing results (Savage et al., 2020). A further indication of the importance of patenting to the Japanese electronics industry is that it has the highest number of employees working as patent information specialists (Japan Patent Office 2017). 


\subsubsection{Independent and Moderating Variables}

Regional diversification refers to the spread of firms' foreign subsidiaries across different geographical regions. Following previous research (Arregle et al., 2009, 2013, 2016), we examine the following regions: NAFTA (15\%), North and Western Europe (17\%), Eastern Europe (3\%), East Asia (37\%), South-Eastern Asia (20\%), South America (3\%), Oceania (2\%), Northwest Asia (2\%), Middle East (1\%), and Africa $(0.4 \%)$.

We follow previous internationalization research (e.g., Lahiri, 2010; Nachum, 2004) and measure regional diversification using the Blau index of diversity (Blau, 1977). We measure regional diversification as follows:

$$
\mathrm{GD}=1-\sum_{i=1}^{N} \mathrm{p}_{\mathrm{i}}^{2},
$$

where $p$ is the percentage of subsidiaries in region $i$ and $N$ is the number of geographical areas. We consider all subsidiaries in each geographical region, regardless of the activities they perform. Regional diversification can take values between zero (i.e., low diversification) and one (i.e., high diversification).

Asset diversification is measured as the percentage of foreign subsidiaries operating in industries different from the MNE's main industry. This measure is based on the idea that firms operating in multiple industries tend to have a more diverse resource base than those operating in a single industry (Cui \& O'Connor, 2012). We used the first two digits of the industry codes (i.e., SIC codes) to determine whether a subsidiary operates in the same or different industry than its parent MNE (Li, 1995; Lu \& Beamish, 2006).

Functional mandate breadth refers to the extent to which the foreign subsidiaries tend to be more specialized versus more generalist. To measure functional mandate breadth, we counted in how many functional areas each subsidiary engages out of four possible options: knowledge-generation (e.g., R\&D, design, software development), manufacturing, sales, and administrative support (Rugman et al., 2011a, 2011b). Next, we aggregated to an MNE-level functional mandate breadth by taking the mean for all subsidiaries.

Institutional distance of the subsidiary portfolio captures the difference between the home country (Japan) and host countries' degree of institutional conditions. We use Corruption Perception Index report to measure this variable (Godinez \& Liu, 2015). We average the rate of corruption perception at the subsidiary portfolio level and then we subtract this score from the average score of Japan.

\subsubsection{Control Variables}

We include the following control variables: firm age measured as the natural logarithm of the number of years since the firm was established, firm size measured as the natural logarithm of the firm's revenues (Arregle et al., 2013), firm public age measured as the natural logarithm of the number of years since the firm's initial 
public offering, $R \& D$ intensity by including the ratio of $\mathrm{R} \& \mathrm{D}$ expenses to sales 1 year before the portfolio characteristics ( $\mathrm{t}-1)$ (Mihalache et al., 2012; Tsai, 2001), prior financial performance $(\mathrm{t}-1)$ measured by the return on equity (i.e., MNE's net income divided by shareholders' equity) (Hoskisson et al., 2002), international experience measured as the number of years since the first subsidiary is established (Delios \& Beamish, 1999), and the percentage of R\&D subsidiaries measured as the proportion of subsidiaries engaged in R\&D (Lavie \& Miller, 2008). Finally, we use the set of dummy variables for the data years to control the external shocks (Gimenez-Fernandez et al., 2020).

\section{Analysis and Results}

The use of patent count as the measurement for MNE innovativeness means that our dependent variable is a count variable with non-negative values. Following previous studies analyzing dependent variables with these characteristics in panel datasets (Chatterji \& Fabrizio, 2014; Huang \& Li, 2019; Wang, 2016), we use the Poisson regression. This is preferred over the conditional negative binomial model for panel data developed by Hausman et al. (1984) because the negative binomial model is not a true fixed-effects method as it does not control for all time-invariant covariates (Allison \& Waterman, 2002; Greene, 2007).

Additionally, we try to control for the possible endogeneity due to simultaneity, which means that there is a possibility of the independent variable affecting the dependent variable, but also that of the dependent variable affecting the independent variable (Hill et al., 2021). To deal with this potential problem of endogeneity, we take an instrumental variables approach (Hill et al., 2021) using a Generalized Method of Moments (GMM) estimator of Poisson regression since we have a count dependent variable (Windmeijer \& Santos Silva, 1997). We implement this instrumental variable GMM Poisson regression in STATA version 16 as per Baum et al. (2003). Following previous studies on the use of instrument variables (Semadeni et al., 2014), we selected two instrument variables in this study: the type of stock market where the MNE is listed and the overall international subsidiary portfolio size. These are appropriate instrumental variables because they influence international diversification, but are not highly correlated with the error terms of the model. That is, the type of stock market signals the status of the firm, which could help the ease of internationalization and the overall subsidiary portfolio size is related to the degree of regional diversification. However, these two variables are not highly correlated to the degree of firm innovation. We also tested empirically the appropriateness of using these instruments. We followed the common approach (Balsmeier et al., 2014) and performed a Hansen's J test, which tests the possible overidentification. The test showed that we cannot reject the null hypothesis that the geographical diversification variable is exogenous (chi-sq $(3)=2.827, p=0.419)$. In short, the results of Hansen's $J$ test indicates that these two instrument variables are valid to use for the model.

Table 1 provides the descriptive statistics and correlations of our model variables. Table 2 provides the results of the instrument variable (IV) Poisson regression using 


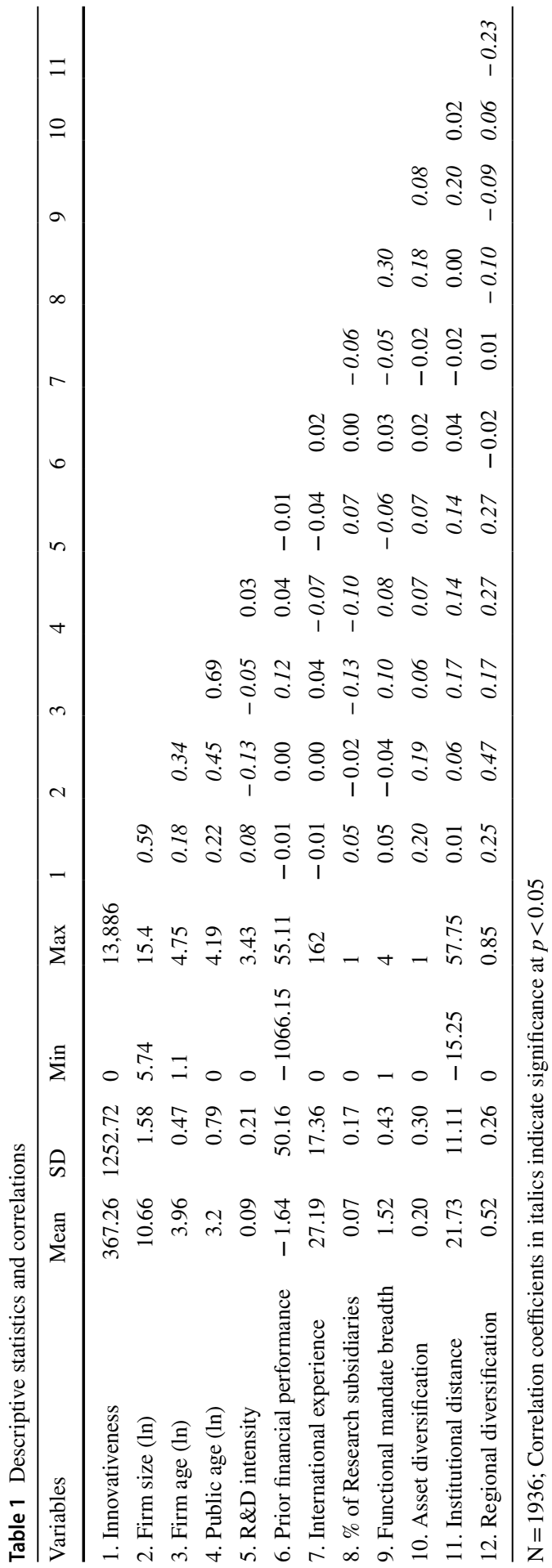




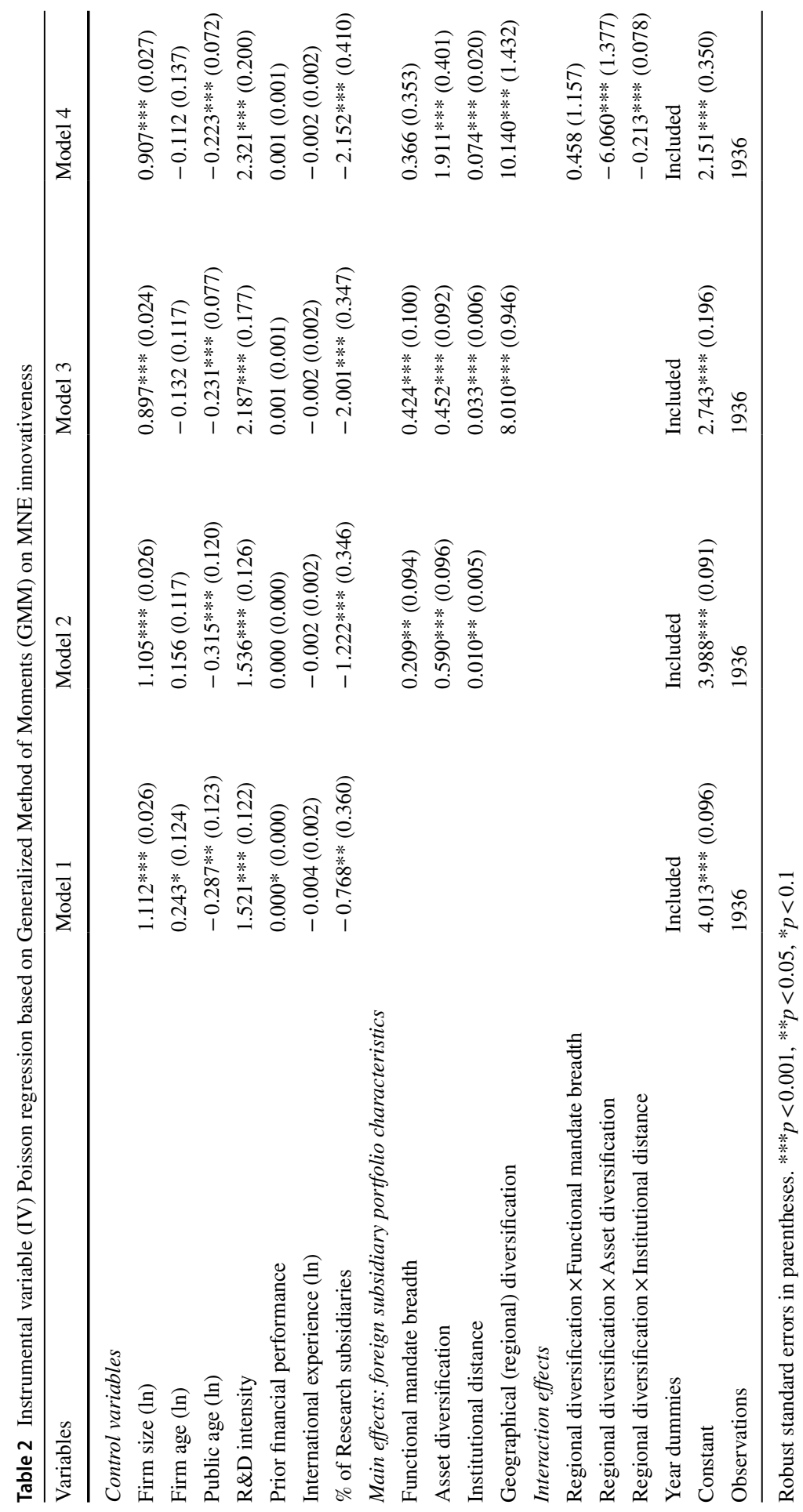


GMM estimators. Model 1 includes only the control variables, Model 2 then adds the moderating variables, Model 3 adds the main effect of the regional diversification, and Model 4 adds the interaction effects of asset diversification, functional mandate breadth and institutional distance. Below, we discuss the results of Model 4 , the full model.

Hypothesis 1 proposes a positive relationship between regional diversification and firm innovativeness. As the coefficient of regional diversification is positive and statistically significant $(\beta=10.140, p<0.001, S E=1.432)$, the results provide support for hypothesis 1 . Further, empirical analysis shows evidence for a negative moderating effect of institutional distance on the main relationship (Hypothesis 2) is supposed as the coefficient is negative and significant $(\beta=-0.213, p<0.001$, $S E=0.078)$. Next, the results are also in line with the hypothesized negative moderating effect of asset diversification (Hypothesis 3) $(\beta=-6.060, p<0.001$, $S E=1.377$ ). However, a moderating effect of functional mandate breadth (Hypothesis 4 ) does not receive support as the interaction between functional mandate breadth and regional diversification show following results $(\beta=0.458, p>0.10, S E=1.157)$. In summary, the empirical results are in line with the effects proposed in hypotheses 1,2 , and 3 , but not hypothesis 4 .

In order to assess the interaction effects in more detail, we provide the graphical illustrations for the significant interaction terms. In Fig. 1, we see that the relationship between regional diversification and MNE innovativeness is positive when considering both low ( $-1 \mathrm{SD})$ and high (+1 SD) levels of institutional distance. But the positive effect is stronger when the institutional distance is low compared to when the institutional distance is high. Thus, the graphical representation of the interaction effect is in line with hypothesis 2 . As shown in Fig. 2, the relationship between regional diversification and firm innovativeness depends on the degree of asset diversification. With low levels of asset diversification (at the lowest possible level, namely zero), firms experience a positive return in the number of patents applied by increasing regional diversification. However, with high levels of asset diversification (at the highest possible level, namely one), this positive effect is less strong. These

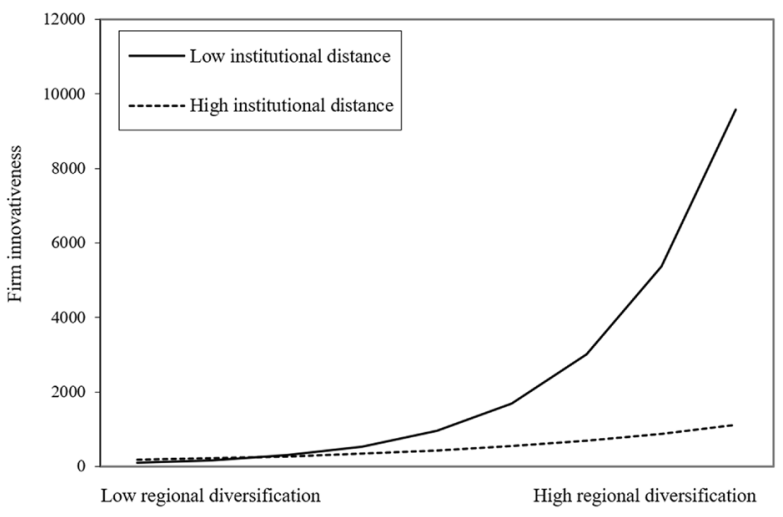

Fig. 1 The interplay between regional diversification and institutional distance on firm innovativeness 


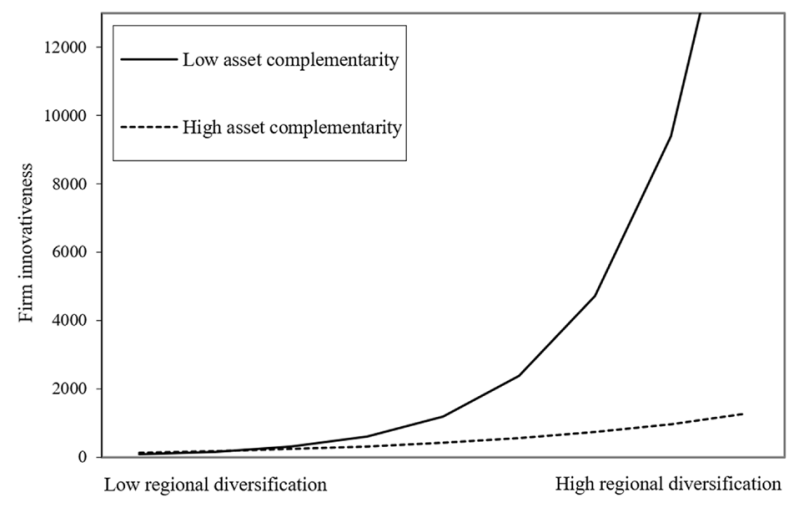

Fig. 2 The interplay between regional diversification and asset diversification on firm innovativeness

results are in line with the relationship proposed in hypothesis 3 . What we can conclude from these two Figures is that the positive relationship between regional diversification and MNE innovativeness is more pronounced for lower levels of institutional distance and asset diversification. Another important insight from Figs. 1 and 2 is that different patterns of internationalization are associated with different levels of innovation. Particularly interesting is the finding that MNEs that match high levels of geographical diversification with high levels of institutional distance or asset diversification tend to have lower innovativeness than their counterparts who match high regional diversification with low institutional distance or asset diversification.

We performed multiple additional statistical tests to check the robustness of the results. First, we used a different measure for our dependent variable, MNE innovativeness. The alternate measure used is based on the count of patents applied at the patent offices in the world instead of just in the Japanese patent office because firms may use different patenting strategies at different patent offices. The results of this additional test are similar to the original ones, both in terms of the direction and statistical significance. Second, we used a different time horizon to lag the dependent variable as it may take longer time to see the effect of geographical diversification in applying for patents. When the lag of the dependent variable is increased by 1 year (i.e., $t+2$ ), the results are again similar to the original ones both in direction and statistical significance. Third, we used a different measurement for our main independent variable by measuring geographical diversification as a count of countries instead of the Blau index of diversity, based on the regions in which the MNE has subsidiaries. Again, the results match the original ones. Fourth, we split the data into two random samples and run the model again. The reason for using this robustness check is that sampling strategy may impact the characteristics of variables. We obtained similar results to the originals ones. Fifth, we checked whether the main relationship could be curvilinear instead of linear. The results show that there is no curvilinear effect as the relationship between the squared-term of regional diversification and firm innovativeness is not statistically significant $(B=-5.366, p=0.169$, $S E=3.905)$. Thus, these additional results indicate that our main results are robust (Appendix). 


\section{Discussion}

This study develops a portfolio perspective of MNE innovativeness by considering how different characteristics of the foreign subsidiary portfolio affect MNEs' ability to leverage their geographical diversification to innovate. Our findings have several key implications for theory. Overall, the portfolio perspective put forward in this study and the empirical findings provide a way to reconcile the contradictory views on how geographical diversification affects innovation. Previous research proposes that internationalization can enhance innovation by providing diverse resources (Narula \& Zanfei, 2005), that it can constrain innovation through increased complexity and reduced knowledge overlap between headquarters and subsidiaries (Bahl et al., 2021; Chen \& Lin, 2018), or that there is an inverted U-shaped relationship such that low to medium levels of internationalization can stimulate innovativeness, while high levels of internationalization can dampen it (Mihalache et al., 2012). Our findings reconcile these divergent views by showing that the extent to which geographical diversification enhances MNE innovation depends on other characteristics of the foreign subsidiary portfolio. Our findings regarding the contingency effects show that increasing geographical (regional) diversification has a more positive influence on MNE innovativeness for lower institutional distance and asset diversification in the subsidiary portfolio. Furthermore, we find that MNEs with high geographical diversification exhibit considerably higher levels of innovativeness when the subsidiary portfolio has low rather than high institutional distance or asset diversification (see Figs. 1 and 2). These findings provide credence to both the enhancing and constraining effects of geographical diversification on innovation as they show that whether one view or the other applies depends on other characteristics of the subsidiary portfolio. In this way, our findings indicate that internationalization can act as a double-edged sword for innovation and that to understand the effect, it is necessary to take a holistic approach to internationalization that considers the contingencies of various characteristics of MNEs' foreign footprint.

In addition, our findings have important theoretical implications as they advance the knowledge-based view of MNEs (Grant, 1996; Regnér \& Zander, 2011). Specifically, our findings advance the knowledge-based view by highlighting the importance of considering knowledge associated with all foreign activities, not only technical knowledge. Previous research in international business adopting a knowledge-based view tends to focus predominantly on technological knowledge associated with R\&D subsidiaries when trying to understand MNE innovativeness (e.g., Jha et al., 2018). Our findings move thinking on MNE innovation beyond foreign R\&D (e.g., Chen et al., 2012; Tojeiro-Rivero \& Moreno, 2019) to the entire portfolio of foreign activities. The significant contributions of previous research on foreign R\&D notwithstanding (for a review, see Papanastassiou et al., 2020), expanding theorizing and analysis to include the entire subsidiary portfolio adds a key missing piece of the puzzle because non-research subsidiaries also provide crucial resources for innovation (Govindarajan \& Ramamurti, 2011; Gupta \& Govindarajan, 2000; Huang \& Li, 2019; Immelt et al., 2009). While previous research shows that particular specific patterns in international organization of R\&D works best (Von Zedtwitz 
\& Gassmann, 2002), our study shows the importance of extending this line of thinking to considering patterns of all value chain activities. In other words, we show that for a comprehensive understanding of global innovation, the entire international footprint matters. In this way, our findings advance Hutzschenreuter and Matt's (2017) argument that knowledge accumulates in the entire portfolio of subsidiaries. Thus, when considering the knowledge resources of a MNE, it is important to take in consideration the entire foreign footprint not only because all activities can potentially provide relevant knowledge for innovation, but also because the MNEs' ability to use its global knowledge resources depends on an intricate interplay between its location and organizational decisions.

Related, previous research using the knowledge-based view of MNEs shows that internationalization provides opportunities to access knowledge (Regnér \& Zander, 2011) and finds that the breadth and depth of international knowledge search are associated with increased exploratory capabilities (Xiao et al., 2020). Our findings show that although there are important opportunities to source knowledge abroad, the MNEs' ability to leverage foreign knowledge to stimulate their innovativeness depends on the institutional distance and asset complementarity of their foreign subsidiary portfolio. Our findings regarding these boundary conditions advance the knowledge-based view of MNEs by showing the importance of developing an internationalization strategy that deliberately considers the structure of all activities that act as foreign sensing mechanisms.

In addition, while previous research did take a portfolio approach to explain the influence of international diversification on MNE financial performance (Delios \& Beamish, 1999; Goerzen \& Beamish, 2003; Kirca et al., 2011; Nachum, 2004; Qian et al., 2008), we show the importance of considering the entire subsidiary portfolio also to understand innovation. This is particularly so, since Lin (2020) recently showed, albeit with a focus on global sourcing, that different configurations are needed for achieving financial and innovation goals. While we know from previous research that foreign locations give MNEs opportunities to learn because subsidiaries are important innovators and providers of knowledge (Phene \& Almeida, 2008), our study highlights the importance of MNEs adopting a portfolio perspective to take full advantage of these learning opportunities and avoid the potential dangers that international expansion poses for innovativeness. Therefore, our findings advance global innovation research (Cano-Kollmann et al., 2016) as we show that adopting a portfolio perspective is crucial for understanding how MNEs can leverage the international context for innovation. Overall, our findings highlight the need for an encompassing and deliberate portfolio-level strategy that considers the interrelatedness of geographic and organizational characteristics to enhance or, at least, safeguard MNE innovativeness.

Furthermore, our study also has implications for location choice research (cf.. Jain et al., 2016; Kim \& Aguilera, 2016). Specifically, our findings provide evidence supporting the semi-globalization perspective (Arregle et al., 2009, 2013). Since we consider geographical diversification at the regional level, we answer Ghemawat's (2003, p. 149) call for a better understanding of the clustering of foreign operations "in order to pursue commonalities more aggressively than would be possible with pure country-by-country adaptation." Another implication of our findings 
for location choice research (e.g., Boeh \& Beamish, 2012; Demirbag \& Glaister, 2010; Romero-Martínez et al., 2019) is by showing that it is important for MNEs to consider their entire existing foreign footprint (Hennart, 2011) when making global location decisions for new subsidiaries. That is, our findings advance previous research showing that experience operating within a location affects future location decisions (Demirbag \& Glaister, 2010; Jain et al., 2016), by showing that, when making location decisions, MNEs should also consider locations of their current operations because the interplay between characteristics in their subsidiary portfolio affects their ability to innovate. Most importantly, our findings advance the discussion of whether location choice is about choosing regions or countries, by showing that when devising a location strategy, it is important to carefully consider it at both the regional and country level. At least when it comes to innovation outcomes, we find that, at the portfolio level, the interplay between the regional dispersion and country characteristics matters. This answers Kim and Aguilera's (2016, p. 18) call for future research to acknowledge MNEs as networks of value-chain activities in multilevel spaces such that their activities are organized differently at the regional and country level to best leverage locational advantages. In this way, our findings show the importance of simultaneously considering embeddedness of subsidiaries at multiple related levels and complement previous studies trying to predict the location choice of individual research subsidiaries by considering both regional and country factors (Lampert et al., 2019).

In addition, while previous research has recognized the importance of asset diversification between foreign subsidiaries and parent firms for subsidiary performance (Lu \& Beamish, 2006; Lu \& Xu, 2006), we show that asset diversification is also an important portfolio-level characteristic, at least for MNEs' innovativeness. This finding advances previous research proposing that subsidiaries' ability to connect with other subsidiaries and the parent company to access and transfer knowledge depends on their embeddedness in the MNE's knowledge network (Achcaoucaou et al., 2014).

Furthermore, we did not find empirical support regarding the role of functional mandate breadth in influencing MNEs' ability to leverage geographical diversification. However, this non-finding is interesting in itself as it has implications for our understanding of subsidiary roles (Meyer et al., 2020) and the geographical disaggregation of value chain activities, which holds that value-chain activities are split into increasingly finer slices that are then performed in locations with comparative advantages for each activity (Contractor et al., 2010). In line with this view, Frost (2001) make the case for the benefits of developing centers of excellence that are leveraged across the global subsidiary network. In our hypothesizing, we expanded this idea to propose that functional specialization can help MNEs leverage geographical diversification. However, the empirical findings were not in line with our theoretical expectations as the functional mandate breadth of the subsidiary portfolio does not appear to influence the relationship between geographical diversification and MNE innovativeness. While our findings do not negate this established view, they do raise the question of whether specialization is a necessary condition or whether it is sufficient that the subsidiary does perform the activity, albeit among others, for which there may be locational advantages. Related, our findings indicate 
that it may not necessarily be the breath of the functional mandate that matters for how MNEs leverage their geographical diversification for innovation, but rather it may be more about the asset base that the subsidiary holds. At the very least, our findings show that it is important to take a holistic view that incorporates the entire portfolio of foreign subsidiaries as there may be important subtleties in how MNEs can become more innovative by going abroad.

Overall, our study's findings advance international business research by developing a portfolio perspective MNE innovation. In this way, we provide a more comprehensive understanding of how firms can leverage the international context to innovate.

\subsection{Managerial Implications}

As organizations increasingly operate across national borders, our study informs managers on how their internationalization strategy affects their ability to leverage the international context for innovation. First, our findings guide managers to consider the entire portfolio of foreign subsidiaries as the locus of innovation. While it is widely accepted that foreign R\&D is important for innovation (Papanastassiou et al., 2020), our study asks managers to go beyond foreign R\&D and look at their entire portfolio of foreign subsidiaries for innovation. Managers should be aware that such opportunities exist because international operations can expose firms to a multitude of stimuli and resources that can enhance innovation alongside foreign R\&D.

Second, our study informs managers that while geographical diversification creates opportunities to increase innovation (Narula \& Zanfei, 2005), whether firms can fully leverage these opportunities depends on the other characteristics of their foreign subsidiary portfolio. Managers should consider that MNEs appear to be better able to benefit from increasing geographical regional diversification to enhance innovation when their foreign subsidiary portfolios have low levels of institutional distance or asset diversification. Furthermore, managers should be wary about internationalization patterns that have high levels of complexity such as when high regional diversification is accompanied by high institutional distance or by high asset diversification in their foreign operations because such MNEs tend to exhibit lower levels of innovativeness than those whose who match high regional diversification with low institutional distance or asset diversification.

Third, when making internationalization decisions, managers should take in consideration their entire foreign subsidiary portfolio. That is, when making a location decision for a new foreign subsidiary, regardless of its mandate, managers should, in addition to considering the characteristics of particular locations (e.g., Boeh \& Beamish, 2012; Romero-Martínez et al., 2019), also map out how this new location fits with the entire portfolio of international subsidiaries that they are already operating abroad. Since global innovation depends on the interplay of geographical and organizational characteristics, managers should consider the overall pattern of international operations when making new internationalization decisions. 


\subsection{Limitations and Future Research}

While this study advances research on internationalization and MNE innovativeness, it has several limitations that need to be considered and addressed in future research. A first consideration is that our findings are based on one industry (i.e., electronics industry). While single-industry studies are popular because the singular setting controls for potential unmeasured factors (e.g., Clò et al., 2020; Gao et al., 2021; Proksch et al., 2019; Speldekamp et al., 2020), it does so at the expense of generalizability. In order to generalize to other populations besides electronics firms, future studies can further probe our portfolio perspective of MNE innovativeness in other industries for a better coverage of the theoretical domain (Geyskens et al., 1998; Shavelson \& Webb, 1991). In addition, since our study did not find empirical evidence in line with the role of functional mandate breadth of the subsidiary portfolio, it might be worthwhile for future research to further consider this matter. One way of doing so can be to focus on changes in the functional mandate of subsidiaries (Gillmore et al., 2020) since such dynamics might be related to changes in the characteristics of the environment in which they operate (Ryan et al., 2018) and thus influence the contributions they have to MNEs' innovation processes. Another avenue for future research is to test which types of organizational designs might work best in terms of helping MNEs to integrate specialized subsidiaries dispersed across geographical borders to allow knowledge transfer and use (Foss et al., 2013). A related direction for future research would take in consideration the integrative mechanisms used to coordinate the foreign subsidiary portfolio as these can have important influence in how subsidiaries contribute resources to the rest of the MNE (Björkman et al., 2004). In addition, our discussion of how firms leverage the international context leaves out one important element in the process: the MNE's decision-makers. Building on previous research showing that top management teams affect firms' ability to leverage foreign environments through their influence on how firms search for knowledge and use geographically dispersed resources (Mihalache et al., 2012), future research can adopt an upper echelon perspective by focusing on the characteristics and processes employed by the top management team as enablers or constraints of how MNEs leverage international diversification.

\subsection{Conclusion}

This study develops a portfolio perspective of MNE innovativeness by moving research beyond a focus on R\&D subsidiaries to consider the entire value chain of activities. We find that to understand the consequences of regional diversification for MNE innovativeness, it is important to consider interrelations with other characteristics of the entire portfolio of international subsidiaries. We hope that our findings regarding the interdependencies of portfolio characteristics on MNE innovativeness will prompt decision-makers to consider new foreign subsidiary decisions not in isolation but as part of deliberate portfolio-level strategy in order to be better positioned to stimulate their global innovation. 


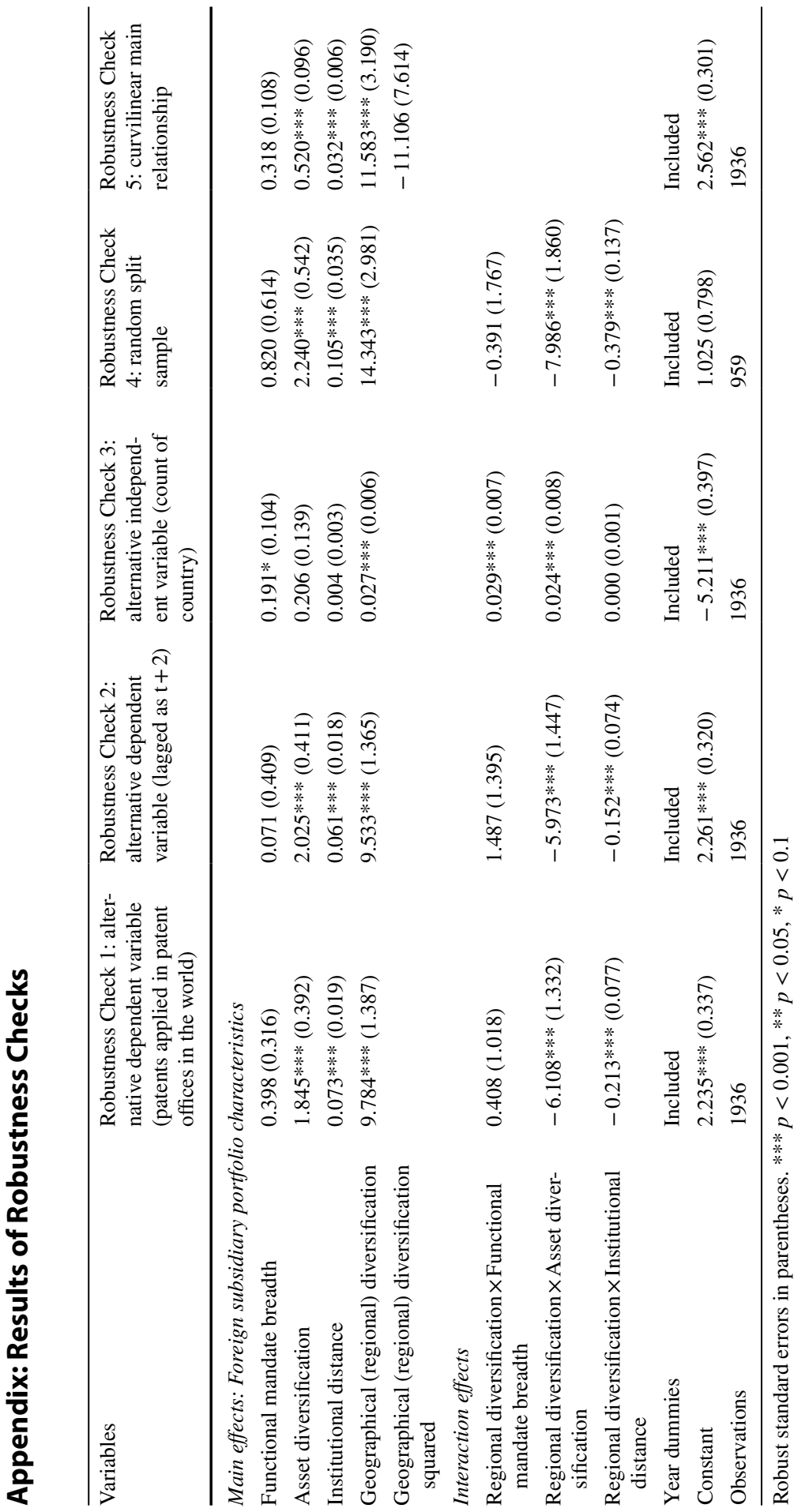


Funding We did not receive any funding for this study.

\section{Declarations}

Conflict of interest There is no conflict of interest in this study.

Data availability The manuscript contains information regarding the data sources.

Code availability Code availability is not applicable for this study.

Open Access This article is licensed under a Creative Commons Attribution 4.0 International License, which permits use, sharing, adaptation, distribution and reproduction in any medium or format, as long as you give appropriate credit to the original author(s) and the source, provide a link to the Creative Commons licence, and indicate if changes were made. The images or other third party material in this article are included in the article's Creative Commons licence, unless indicated otherwise in a credit line to the material. If material is not included in the article's Creative Commons licence and your intended use is not permitted by statutory regulation or exceeds the permitted use, you will need to obtain permission directly from the copyright holder. To view a copy of this licence, visit http://creativecommons.org/licen ses/by/4.0/.

\section{References}

Achcaoucaou, F., Miravitlles, P., \& León-Darder, F. (2014). Knowledge sharing and subsidiary R\&D mandate development: A matter of dual embeddedness. International Business Review, 23(1), 76-90.

Allison, P. D., \& Waterman, R. P. (2002). Fixed-effects negative binomial regression models. Sociological Methodology, 32(1), 247-265.

Almeida, P., Song, J., \& Grant, R. M. (2002). Are firms superior to alliances and markets? An empirical test of cross-border knowledge building. Organization Science, 13(2), 147-161.

Ambos, T. C., Ambos, B., \& Schlegelmilch, B. B. (2006). Learning from foreign subsidiaries: An empirical investigation of headquarters' benefits from reverse knowledge transfers. International Business Review, 15(3), 294-312.

Anderson, P. (1999). Perspective: Complexity theory and organization science. Organization Science, 10(3), 216-232.

Arregle, J. L., Beamish, P. W., \& Hebert, L. (2009). The regional dimension of MNE's foreign subsidiary localization. Journal of International Business Studies, 40(1), 86-107.

Arregle, J. L., Miller, T. L., Hitt, M. A., \& Beamish, P. W. (2013). Do regions matter? An integrated institutional and semiglobalization perspective on the internationalization of MNEs. Strategic Management Journal, 34(8), 910-934.

Arregle, J. L., Miller, T. L., Hitt, M. A., \& Beamish, P. W. (2016). How does regional institutional complexity affect MNE internationalization? Journal of International Business Studies, 47(6), 697-722.

Asmussen, C. G., Pedersen, T., \& Dhanaraj, C. (2009). Host-country environment and subsidiary competence: Extending the diamond network model. Journal of International Business Studies, 40(1), 42-57.

Asmussen, C. G., Pedersen, T., \& Petersen, B. (2007). How do we capture "global specialization" when measuring firms' degree of globalization? Management International Review, 47(6), 791-813.

Azar, G., \& Drogendijk, R. (2014). Psychic distance, innovation, and firm performance. Management International Review, 54(5), 581-613.

Bahl, M., Lahiri, S., \& Mukherjee, D. (2021). Managing internationalization and innovation tradeoffs in entrepreneurial firms: Evidence from transition economies. Journal of World Business, 56(1), 101150. 
Balsmeier, B., Buchwald, A., \& Stiebale, J. (2014). Outside directors on the board and innovative firm performance. Research Policy, 43(10), 1800-1815.

Baum, C. F., Schaffer, M. E., \& Stillman, S. (2003). Instrumental variables and GMM: Estimation and testing. The Stata Journal, 3(1), 1-31.

Berry, H. (2014). Global integration and innovation: Multicountry knowledge generation within MNCs. Strategic Management Journal, 35(6), 869-890.

Birkinshaw, J., \& Pedersen, T. (2009). Strategy and management in MNE subsidiaries. In A. M. Rugman (Ed.), The Oxford handbook of international business (2nd ed., pp. 367-388). Oxford University Press.

Björkman, I., Barner-Rasmussen, W., \& Li, L. (2004). Managing knowledge transfer in MNCs: The impact of headquarters control mechanisms. Journal of International Business Studies, 35(5), 443-455.

Blau, P. (1977). Inequality and heterogeneity: A primitive theory of social structure. Free Press.

Boeh, K. K., \& Beamish, P. W. (2012). Travel time and the liability of distance in foreign direct investment: Location choice and entry mode. Journal of International Business Studies, 43(5), 525-535.

Buckley, P. J., Clegg, J., Forsans, N., \& Reilly, K. T. (2001). Increasing the size of the country: Regional economic integration and foreign direct investment in a globalised world economy. Management International Review, 41(3), 251-274.

Cano-Kollmann, M., Cantwell, J., Hannigan, T. J., Mudambi, R., \& Song, J. (2016). Knowledge connectivity: An agenda for innovation research in international business. Journal of International Business Studies, 47(3), 255-262.

Cantwell, J. A. (1989). Technological innovation and multinational corporations. Basil Blackwell.

Chatterji, A. K., \& Fabrizio, K. R. (2014). Using users: When does external knowledge enhance corporate product innovation? Strategic Management Journal, 35(10), 1427-1445.

Chen, C. J., Huang, Y. F., \& Lin, B. W. (2012). How firms innovate through R\&D internationalization? An S-curve hypothesis. Research Policy, 41(9), 1544-1554.

Chen, S., \& Lin, N. (2018). The effect of inter- and intra-organizational distances on success of offshored outsourced innovation: A configurational approach. Journal of Business Research, 103, 519-529.

Chesbrough, H. W., \& Teece, D. J. (1996). Organizing for innovation: When is virtual virtuous? Harvard Business Review, 74(1), 65-73.

Ciabuschi, F., Martín, O. M., \& Ståhl, B. (2010). Headquarters' influence on knowledge transfer performance. Management International Review, 50(4), 471-491.

Clò, S., Florio, M., \& Rentocchini, F. (2020). Firm ownership, quality of government and innovation: Evidence from patenting in the telecommunication industry. Research Policy, 49(5), 103960.

Contractor, F. J., Kumar, V., Kundu, S. K., \& Pedersen, T. (2010). Reconceptualizing the firm in a world of outsourcing and offshoring: The organizational and geographical relocation of high-value company functions. Journal of Management Studies, 47(8), 1417-1433.

Crespo, C. F., Griffith, D. A., \& Lages, L. F. (2014). The performance effects of vertical and horizontal subsidiary knowledge outflows in multinational corporations. International Business Review, 23(5), 993-1007.

Cui, A. S., \& O’Connor, G. (2012). Alliance portfolio resource diversity and firm innovation. Journal of Marketing, 76(4), 24-43.

da Silva Lopes, T., Casson, M., \& Jones, G. (2019). Organizational innovation in the multinational enterprise: Internalization theory and business history. Journal of International Business Studies, 50(8), 1338-1358.

Delios, A., \& Beamish, P. W. (1999). Geographic scope, product diversification, and the corporate performance of Japanese firms. Strategic Management Journal, 20(8), 711-727.

Demirbag, M., \& Glaister, K. W. (2010). Factors determining offshore location choice for R\&D projects: A comparative study of developed and emerging regions. Journal of Management Studies, 47(8), 1534-1560.

Driffield, N., Love, J. H., \& Yang, Y. (2016). Reverse international knowledge transfer in the MNE: (Where) does affiliate performance boost parent performance? Research Policy, 45(2), 491-506.

Feinberg, S. E., \& Gupta, A. K. (2004). Knowledge spillovers and the assignment of R\&D responsibilities to foreign subsidiaries. Strategic Management Journal, 25(8-9), 823-845.

Foss, N. J., Lyngsie, J., \& Zahra, S. A. (2013). The role of external knowledge sources and organizational design in the process of opportunity exploitation. Strategic Management Journal, 34(12), 1453-1471. 
Foucart, R., \& Li, Q. C. (2021). The role of technology standards in product innovation: Theory and evidence from UK manufacturing firms. Research Policy, 50(2), 104157.

Frost, T. (2001). The geographic sources of foreign subsidiaries' innovations. Strategic Management Journal, 22(2), 101-123.

Gao, Y., Hu, Y., Liu, X., \& Zhang, H. (2021). Can public R\&D subsidy facilitate firms' exploratory innovation? The heterogeneous effects between central and local subsidy programs. Research Policy, 50(4), 104221.

Geyskens, I., Steenkamp, J.-B.E.M., \& Kumar, N. (1998). Generalizations about trust in marketing channel relationships using meta-analysis. International Journal of Research in Marketing, 15(3), 223-248.

Ghemawat, P. (2003). Semiglobalization and international business strategy. Journal of International Business Studies, 34(2), 138-152.

Ghoshal, S., \& Nohria, N. (1989). Internal differentiation within multinational corporations. Strategic Management Journal, 10(4), 323-337.

Gillmore, E., Andersson, U., \& Ekman, P. (2020). The enduring effects of relational attributes on subsidiary evolution after mandate loss. Global Strategy Journal, 11(3), 402-433. https://doi.org/10.1002/ gsj.1391

Gimenez-Fernandez, E. M., Sandulli, F. D., \& Bogers, M. (2020). Unpacking liabilities of newness and smallness in innovative start-ups: Investigating the differences in innovation performance between new and older small firms. Research Policy, 49(10), 104049.

Godinez, J. R., \& Liu, L. (2015). Corruption distance and FDI flows into Latin America. International Business Review, 24(1), 33-42.

Goerzen, A., \& Beamish, P. W. (2003). Geographic scope and multinational enterprise performance. Strategic Management Journal, 24(13), 1289-1306.

Govindarajan, V., \& Ramamurti, R. (2011). Reverse innovation, emerging markets, and global strategy. Global Strategy Journal, 1(3-4), 191-205.

Grant, R. M. (1996). Toward a knowledge-based theory of the firm. Strategic Management Journal, 17(S2), 109-122.

Greene, W. (2007). Fixed and Random Effects Models for Count Data. Working Paper. Department of Economics, Stern School of Business, New York University.

Griliches, Z. (1998). Patent statistics as economic indicators: A survey. In Z. Griliches (Ed.), $R \& D$ and productivity: the econometric evidence (pp. 287-343). University of Chicago Press.

Gupta, A. K., \& Govindarajan, V. (2000). Knowledge flows within multinational corporations. Strategic Management Journal, 21(4), 473-496.

Hagedoorn, J., \& Cloodt, M. (2003). Measuring innovative performance: Is there an advantage in using multiple indicators? Research Policy, 32(8), 1365-1379.

Hausman, J., Hall, B., \& Griliches, Z. (1984). Econometric models for count data with an application to the patents-R\&D relationship. Econometrica, 52(4), 909-938.

Hennart, J. F. (2011). A theoretical assessment of the empirical literature on the impact of multinationality on performance. Global Strategy Journal, 1(1-2), 135-151.

Hill, A. D., Johnson, S. G., Greco, L. M., O’Boyle, E. H., \& Walter, S. L. (2021). Endogeneity: A review and agenda for the methodology-practice divide affecting micro and macro research. Journal of Management, 47(1), 105-143.

Hitt, M. A., Ireland, R. D., \& Hoskisson, R. E. (2007). Strategic management: Competitiveness and globalization (7th ed.). South-Western.

Hitt, M. A., Tihanyi, L., Miller, T., \& Connelly, B. (2006). International diversification: Antecedents, outcomes, and moderators. Journal of Management, 32(6), 831-867.

Holm, U., \& Sharma, D. D. (2006). Subsidiary marketing knowledge and strategic development of the multinational corporation. Journal of International Management, 12(1), 47-66.

Hoskisson, R. E., Hitt, M. A., Johnson, R. A., \& Grossman, W. (2002). Conflicting voices: The effects of institutional ownership heterogeneity and internal governance on corporate innovation strategies. Academy of Management Journal, 45(4), 697-716.

Hsu, C. W., Lien, Y. C., \& Chen, H. (2015). R\&D internationalization and innovation performance. International Business Review, 24(2), 187-195.

Huang, K. G., \& Li, J. (2019). Adopting knowledge from reverse innovations? Transnational patents and signaling from an emerging economy. Journal of International Business Studies, 50(7), 1078-1102. 
Hutzschenreuter, T., \& Matt, T. (2017). MNE internationalization patterns, the roles of knowledge stocks, and the portfolio of MNE subsidiaries. Journal of International Business Studies, 48(9), 1131-1150.

Immelt, J. R., Govindarajan, V., \& Trimble, C. (2009). How GE is disrupting itself. Harvard Business Review, 87(10), 56-65.

Jain, N. K., Kothari, T., \& Kumar, V. (2016). Location choice research: Proposing new agenda. Management International Review, 56(3), 303-324.

Japan Ministry of Economy, Trade and Industry. (2017). Whitepaper on Manufacturing. Retrieved March 24, 2018, from http://www.meti.go.jp/report/whitepaper/mono/2017/honbun_pdf/index.html.

Japan Patent Office (2017). Annual Report. Retrieved March 25, 2018, from https://www.jpo.go.jp/shiry ou/toushin/nenji/nenpou2017_index.htm.

Jensen, P. D. Ø., Larsen, M. M., \& Pedersen, T. (2013). The organizational design of offshoring: Taking stock and moving forward. Journal of International Management, 19(4), 315-323.

Jha, S. K., Dhanaraj, C., \& Krishnan, R. T. (2018). From arbitrage to global innovation: Evolution of multinational R\&D in emerging markets. Management International Review, 58(4), 633-661.

Jiang, R. J., Tao, Q. T., \& Santoro, M. D. (2010). Alliance portfolio diversity and firm performance. Strategic Management Journal, 31(10), 1136-1144.

Katila, R., \& Ahuja, G. (2002). Something old, something new: A longitudinal study of search behavior and new product introductions. Academy of Management Journal, 45(6), 1183-1194.

Kedia, B. L., \& Mukherjee, D. (2009). Understanding offshoring: A research framework based on disintegration, location and externalization advantages. Journal of World Business, 44(3), 250-261.

Khanna, T., \& Palepu, K. (1997). Why focused strategies may be wrong for emerging markets. Harvard Business Review, 75(4), 41-43.

Kijkuit, B., \& Van den Ende, J. (2010). With a little help from our colleagues: A longitudinal study of social networks for innovation. Organization Studies, 31(4), 451-479.

Kim, J. U., \& Aguilera, R. V. (2016). Foreign location choice: Review and extensions. International Journal of Management Reviews, 18(2), 133-159.

Kirca, A. H., Hult, G. T. M., Roth, K., Cavusgil, S. T., Perryy, M. Z., Akdeniz, M. B., Deligonul, S. Z., Mena, J. A., Pollitte, W. A., Hoppner, J. J., Miller, J. C., \& White, R. C. (2011). Firm-specific assets, multinationality, and financial performance: A meta-analytic review and theoretical integration. Academy of Management Journal, 54(1), 47-72.

Kogut, B., \& Zander, U. (1992). Knowledge of the firm, combinative capabilities, and the replication of technology. Organization Science, 3(3), 383-397.

Kostova, T. (1999). Transnational transfer of strategic organizational practices: A contextual perspective. Academy of Management Review, 24(2), 308-324.

Kostova, T., Beugelsdijk, S., Scott, W. R., Kunst, V. E., Chua, C. H., \& van Essen, M. (2020). The construct of institutional distance through the lens of different institutional perspectives: Review, analysis, and recommendations. Journal of International Business Studies, 51(4), 467-497.

Kostova, T., \& Roth, K. (2002). Adoption of an organizational practice by subsidiaries of multinational corporations: Institutional and relational effects. Academy of Management Journal, 45(1), 215-233.

Kotabe, M., Dunlap-Hinkler, D., Parente, R., \& Mishra, H. A. (2007). Determinants of cross-national knowledge transfer and its effect on firm innovation. Journal of International Business Studies, $38(2), 259-282$.

Kuemmerle, W. (1999). The drivers of foreign direct investment into research and development: An empirical investigation. Journal of International Business Studies, 30(1), 1-24.

Lahiri, N. (2010). Geographic distribution of R\&D activity: How does it affect innovation quality? Academy of Management Journal, 53(5), 1194-1209.

Lampert, C. M., Kim, M., Hubbard, T. D., Roy, R., \& Leckie, G. (2019). Fearlessly swimming upstream to risky waters: The role of geographic entry in innovation. Journal of Management Studies, 56(7), 1377-1413.

Lavie, D., \& Miller, S. R. (2008). Alliance portfolio internationalization and firm performance. Organization Science, 19(4), 623-646.

Lee, J. Y., Jiménez, A., \& Bhandari, K. R. (2020). Subsidiary roles and dual knowledge flows between MNE subsidiaries and headquarters: The moderating effects of organizational governance types. Journal of Business Research, 108(1), 188-200.

Leiponen, A., \& Helfat, C. E. (2010). Innovation objectives, knowledge sources, and the benefits of breadth. Strategic Management Journal, 31(2), 224-236. 
Lewin, A. Y., \& Peeters, C. (2006). Offshoring work: Business hype or the onset of fundamental transformation? Long Range Planning, 39(3), 221-239.

Li, J. (1995). Foreign entry and survival: Effects of strategic choices on performance in international markets. Strategic Management Journal, 16(5), 333-351.

Lin, N. (2020). Designing global sourcing strategy for cost savings and innovation: A configurational approach. Management International Review, 60(5), 723-753.

Lu, J. W., \& Beamish, P. W. (2004). International diversification and firm performance: The S-curve hypothesis. Academy of Management Journal, 47(4), 598-609.

Lu, J. W., \& Beamish, P. W. (2006). Partnering strategies and performance of SMEs' international joint ventures. Journal of Business Venturing, 21(4), 461-486.

Lu, J. W., \& Xu, D. (2006). Growth and survival of international joint ventures: An external-internal legitimacy perspective. Journal of Management, 32(3), 426-448.

Luo, Y. (2002). Product diversification in international joint ventures: Performance implications in an emerging market. Strategic Management Journal, 23(1), 1-20.

Luo, Y., \& Peng, M. W. (1999). Learning to compete in a transition economy: Experience, environment, and performance. Journal of International Business Studies, 30(2), 269-296.

Matysiak, L., Rugman, A. M., \& Bausch, A. (2018). Dynamic capabilities of multinational enterprises: The dominant logics behind sensing, seizing, and transforming matter! Management International Review, 58(2), 225-250.

Meyer, K. E., Li, C., \& Schotter, A. P. (2020). Managing the MNE subsidiary: Advancing a multilevel and dynamic research agenda. Journal of International Business Studies, 51(4), 538-576.

Meyer, K. E., Mudambi, R., \& Narula, R. (2011). Multinational enterprises and local contexts: The opportunities and challenges of multiple embeddedness. Journal of Management Studies, 48(2), $235-252$.

Michailova, S., \& Mustaffa, Z. (2012). Subsidiary knowledge flows in multinational corporations: Research accomplishments, gaps, and opportunities. Journal of World Business, 47(3), 383-396.

Mihalache, O. R., Jansen, J. J., Van Den Bosch, F. A., \& Volberda, H. W. (2012). Offshoring and firm innovation: The moderating role of top management team attributes. Strategic Management Journal, 33(13), 1480-1498.

Mihalache, M., \& Mihalache, O. R. (2020). What is offshoring management capability and how do organizations develop it? A study of Dutch IT service providers. Management International Review, 60(1), 37-67.

Motohashi, K. (2008). Licensing or not licensing? An empirical analysis of the strategic use of patents by Japanese firms. Research Policy, 37(9), 1548-1555.

Mudambi, R. (1999). MNE internal capital markets and subsidiary strategic independence. International Business Review, 8(2), 197-211.

Mudambi, R., \& Swift, T. (2011). Leveraging knowledge and competencies across space: The next frontier in international business. Journal of International Management, 17(3), 186-189.

Nachum, L. (2004). Geographic and industrial diversification of developing country firms. Journal of Management Studies, 41(2), 273-294.

Najafi-Tavani, Z., Giroud, A., \& Andersson, U. (2014). The interplay of networking activities and internal knowledge actions for subsidiary influence within MNCs. Journal of World Business, 49(1), 122-131.

Nambisan, S. (2013). Industry technical committees, technological distance, and innovation performance. Research Policy, 42(4), 928-940.

Narula, R. (2017). Emerging market MNEs as meta-integrators: The importance of internal networks. International Journal of Technology Management, 74(1-4), 214-220.

Narula, R., \& Zanfei, A. (2005). Globalisation of innovation: The role of multinational enterprises. In J. Fagerberg, D. Mowery, \& R. R. Nelson (Eds.), Handbook of innovation (pp. 318-347). Oxford University Press.

Nieto, M. J., \& Rodríguez, A. (2011). Offshoring of R\&D: Looking abroad to improve innovation performance. Journal of International Business Studies, 42(3), 345-361.

Papanastassiou, M., Pearce, R., \& Zanfei, A. (2020). Changing perspectives on the internationalization of R\&D and innovation by multinational enterprises: A review of the literature. Journal of International Business Studies, 51(4), 623-664. 
Penner-Hahn, J., \& Shaver, J. M. (2005). Does international research and development increase patent output? An analysis of Japanese pharmaceutical firms. Strategic Management Journal, 26(2), 121-140.

Pennings, J. M., \& Harianto, F. (1992). Technological networking and innovation implementation. Organization Studies, 3(3), 356-382.

Phene, A., \& Almeida, P. (2008). Innovation in multinational subsidiaries: The role of knowledge assimilation and subsidiary capabilities. Journal of International Business Studies, 39(5), 901-919.

Proksch, D., Busch-Casler, J., Haberstroh, M. M., \& Pinkwart, A. (2019). National health innovation systems: Clustering the OECD countries by innovative output in healthcare using a multi indicator approach. Research Policy, 48(1), 169-179.

Qian, G., Li, L., Li, J., \& Qian, Z. (2008). Regional diversification and firm performance. Journal of International Business Studies, 39(2), 197-214.

Raziq, M. M., Benito, G. R., \& Ahmad, M. (2021). Institutional distance and MNE-subsidiary initiative collaboration: The role of dual embeddedness. European Management Review, 18(3), 311328. https://doi.org/10.1111/emre.12454

Regner, P., \& Zander, U. (2011). Knowledge and strategy creation in multinational companies. Management International Review, 51(6), 821-850.

Rodrigues, C. D., Borini, F. M., Raziq, M. M., \& Bernardes, R. C. (2020). The roles of external embeddedness and institutional distance in the subsidiary product/process innovation and R\&D capacity. Journal of Knowledge Management, 24(10), 2513-2530.

Romero-Martínez, A. M., García-Muiña, F. E., Chidlow, A., \& Larimo, J. (2019). Formal and informal institutional differences between home and host country and location choice: Evidence from the Spanish Hotel Industry. Management International Review, 59(1), 41-65.

Roper, S., \& Hewitt-Dundas, N. (2015). Knowledge stocks, knowledge flows and innovation: Evidence from matched patents and innovation panel data. Research Policy, 44(7), 1327-1340.

Rothaermel, F. T., Hitt, M. A., \& Jobe, L. A. (2006). Balancing vertical integration and strategic outsourcing: Effects on product portfolio, product success, and firm performance. Strategic Management Journal, 27(11), 1033-1056.

Rugman, A., Verbeke, A., \& Yuan, W. (2011a). Reconceptualizing Bartlett and Ghoshal's classification of national subsidiary roles in the multinational enterprise. Journal of Management Studies, 48(2), 253-277.

Rugman, A. M., Verbeke, A., \& Nguyen, Q. T. (2011b). Fifty years of international business theory and beyond. Management International Review, 51(6), 755-786.

Ryan, P., Giblin, M., Andersson, U., \& Clancy, J. (2018). Subsidiary knowledge creation in co-evolving contexts. International Business Review, 27(5), 915-932.

Sampat, B. N., \& Shadlen, K. C. (2017). Secondary pharmaceutical patenting: A global perspective. Research Policy, 46(3), 693-707.

Savage, J. P., Li, M., Turner, S. F., Hatfield, D. E., \& Cardinal, L. B. (2020). Mapping patent usage in management research: The state of prior art. Journal of Management, 46(6), 1121-1155.

Semadeni, M., Withers, M. C., \& Certo, S. T. (2014). The perils of endogeneity and instrumental variables in strategy research: Understanding through simulations. Strategic Management Journal, 35(7), 1070-1079.

Shavelson, R., \& Webb, N. M. (1991). Generalizability theory: A primer. Sage.

Shirodkar, V., \& Konara, P. (2017). Institutional distance and foreign subsidiary performance in emerging markets: Moderating effects of ownership strategy and host-country experience. Management International Review, 57(2), 179-207.

Song, M., Droge, C., Hanvanich, S., \& Calantone, R. (2005). Marketing and technology resource complementarity: An analysis of their interaction effect in two environmental contexts. Strategic Management Journal, 26(3), 259-276.

Speldekamp, D., Knoben, J., \& Saka-Helmhout, A. (2020). Clusters and firm-level innovation: A configurational analysis of agglomeration, network and institutional advantages in European aerospace. Research Policy, 49(3), 103921.

Tippmann, E., Scott, P. S., \& Mangematin, V. (2012). Problem solving in MNCs: How local and global solutions are (and are not) created. Journal of International Business Studies, 43(8), 746-771.

Tojeiro-Rivero, D., \& Moreno, R. (2019). Technological cooperation, R\&D outsourcing, and innovation performance at the firm level: The role of the regional context. Research Policy, 48(7), 1798-1808.

Toyo Keizai. (2010). Kaigai Shinshutsu Kigyou Souran Kuni Betsu. Tokyo: Toyo Keizai. 
Trott, P., \& Simms, C. (2017). An examination of product innovation in low- and medium-technology industries: Cases from the UK packaged food sector. Research Policy, 46(3), 605-623.

Tsai, W. (2001). Knowledge transfer in intraorganizational networks: Effects of network position and absorptive capacity on business unit innovation and performance. Academy of Management Journal, 44(5), 996-1004.

Von Zedtwitz, M., \& Gassmann, O. (2002). Market versus technology drive in R\&D internationalization: Four different patterns of managing research and development. Research Policy, 31(4), 569-588.

Vrontis, D., \& Christofi, M. (2019). R\&D internationalization and innovation: A systematic review, integrative framework and future research directions. Journal of Business Research, 128(5), 812-823.

Wang, J. (2016). Knowledge creation in collaboration networks: Effects of tie configuration. Research Policy, 45(1), 68-80.

Wiersema, M. F., \& Bowen, H. P. (2011). The relationship between international diversification and firm performance: Why it remains a puzzle. Global Strategy Journal, 1(1-2), 152-170.

Williams, C., \& Lee, S. H. (2011). Entrepreneurial contexts and knowledge coordination within the multinational corporation. Journal of World Business, 46(2), 253-264.

Williams, C., \& Nones, B. (2009). R\&D subsidiary isolation in knowledge-intensive industries: Evidence from Austria. $R$ and D Management, 39(1), 111-123.

Windmeijer, F. A. G., \& Santos Silva, J. M. C. (1997). Endogeneity in count data models: An application to demand for health care. Journal of Applied Econometrics, 12(3), 281-294.

Wu, H., Chen, J., \& Jiao, H. (2016). Dynamic capabilities as a mediator linking international diversification and innovation performance of firms in an emerging economy. Journal of Business Research, 69(8), 2678-2686.

Wu, J., \& Park, S. H. (2019). The role of international institutional complexity on emerging market multinational companies' innovation. Global Strategy Journal, 9(2), 333-353.

Xiao, S. S., Lew, Y. K., \& Park, B. I. (2020). International network searching, learning, and explorative capability: Small and medium-sized enterprises from China. Management International Review, 60(4), 597-621.

Yang, Q., Mudambi, R., \& Meyer, K. E. (2008). Conventional and reverse knowledge flows in multinational corporations. Journal of Management, 34(5), 882-902.

Zheng, Y., \& Yang, H. (2015). Does familiarity foster innovation? The impact of alliance partner repeatedness on breakthrough innovations. Journal of Management Studies, 52(2), 213-230.

Publisher's Note Springer Nature remains neutral with regard to jurisdictional claims in published maps and institutional affiliations.

\section{Authors and Affiliations}

\section{Mashiho Mihalache ${ }^{1}$ D $\cdot$ Oli R. Mihalache ${ }^{2,3} \cdot$ Jan van den Ende ${ }^{4}$}

Oli R. Mihalache

oli.mihalache@gmail.com

Jan van den Ende

jende@rsm.nl

1 Amsterdam Business School, University of Amsterdam, P.O. Box 15953, 1001 NL Amsterdam, The Netherlands

2 Athabasca University, Faculty of Business, 1 University Dr, Athabasca, Alberta, Canada

3 Vrije Universiteit Amsterdam, School of Business and Economics, De Boelelaan 1105, 1081 HV Amsterdam, The Netherlands

4 Rotterdam School of Management, Erasmus University, Burgemeester Oudlaan 50, 3062 PA Rotterdam, The Netherlands 